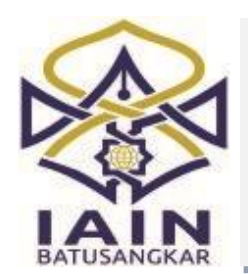

JURNAL TA'DIB, Vol 22 (1), 2019, (Januari-Juni)

ISSN: 1410-8208 (Print) 2580-2771 (Online)

Tersedia online di http://ecampus.iainbatusangkar.ac.id/ojs/index.php/takdib/index

\title{
SIM (Sistem Informasi Manajemen) Kurikulum Perguruan Tinggi Keagamaan Islam Berbasis CMS Wordpress
}

\author{
Badrudin*) \\ Universitas Islam Negeri Sunan Gunung \\ Djati Bandung, Jawa Barat, Indonesia \\ Email: dr.badrudin@uinsgd.ac.id

\section{Rayan Nurdin} \\ Universitas Islam Negeri Sunan Gunung \\ Djati Bandung, Jawa Barat, Indonesia \\ Email: rayanneutron@gmail.com
}

\begin{abstract}
Abstrak: This study aims to examine Islamic Religious Colleges curriculum information systems based on wordpress CMS. Specifically, this study purposes to explore: 1) the planning of the use of curriculum MIS based on CMS WordPress. 2) the implementation of curriculum MIS which is based on Wordpress CMS, 3) Evaluation of the use of Wordpress CMS-based curriculum MIS. 4) The design concept of the curriculum MIS model based on WordPress CMS. The study used a qualitative approach with a case study of the curriculum Management Information System at the Islamic Education Management (MPI) Study Program of Faculty of Tarbiyah and Teacher Training Islamic University Sunan Gunung Djati (FTIK UIN SGD) Bandung. The subjects of this study were the Chair of the MPI Study Program UIN SGD Bandung, MPI Study Program Information System Operator and the Word CMS application used by the institution. The results of the study show that the MPI Study Program FTIK UIN SGD Bandung used a Curriculum MIS based on Wordpress CMS, and it has succesfully facilitated the students, lecturers, and stakeholders to access the curriculum of study programs easier.
\end{abstract}

*) Corresponding Author
PTKI dari segi mutu dan relevansi.

PENDAHULUAN

$\mathrm{R}$ evolusi industri 4.0 semakin berkembang pesat dalam semua bidang kehidupan termasuk pendidikan. Perguruan Tinggi Keagamaan Islam penting mengembangkan SIM (Sistem Informasi Manajemen) pendidikan yang lebih baik. Menghadapi era revolusi industri 4.0, lembaga pendidikan tinggi dituntut mampu mengembangkan SIM pendidikan termasuk SIM kurikulum guna meningkatkan mutu layanan pendidikan. Umumnya, pengelolaan kurikulum pada PTKI (Perguruan Tinggi Keagamaan Islam) di Indonesia belum menggunakan sistem informasi manajemen yang memadai. Beberapa penelitian kurikulum PTKI telah dilakukan oleh sejumlah peneliti. Alhamuddin (2016) meneliti kurikulum
Penelitian tersebut menyimpulkan bahwa: "perlu adanya frameworks of thinking (kerangka berfikir) yang jelas dalam pengembangan kurikulum pendidikan tinggi agama Islam untuk mencapai tujuan pendidikan yang ditetapkan serta berimplikasi pada mutu lulusan dan perguruan tinggi." Berbicara mutu dan relevansi, kurikulum PT (Perguruan Tinggi) harus dikembangkan mengacu pada kerangka yang termaktub pada KKNI. Realitas yang terjadi, implementasi kurikulum berbasis KKNI dan SNPT pada setiap PT bervariasi disebabkan pemahaman yang belum memadai dari seluruh PT khususnya PTKI. Suwadi (2016) meneliti kurikulum dengan judul Pengembangan Kurikulum PAI pada Pendidikan Tinggi. 
Penelitian tersebut meninjau pengembangan kurikulum pendidikan tinggi dengan mengacu pada KKNI-SNPT berparadigma integrasi-interkoneksi di Program Studi PAI FITK UIN Sunan Kalijaga Jogjakarta. Adapun penelitian CMS Wordpress di antaranya dilakukan P. Anjarkusuma \& Bambang (2014) yang meneliti penggunaan aplikasi CMS Wordpress untuk merancang website sebagai media promosi pada Maroon Wedding Malang. Penelitian tersebut bertujuan untuk meningkatkan promosi perusahaan dengan menggunakan website. Penelitian tersebut menyimpulkan bahwa website menggunakan CMS Wordpress memiliki perkembangan yang cukup baik, website memiliki tampilan yang menarik dan mudah digunakan sehingga pengguna tidak bingung dalam pengoperasiannya.

Umumnya penelitian kurikulum perguruan tinggi difokuskan pada penyusunan dan pengembangan kurikulum berbasis KKNI dan SNPT. Berbeda dengan kajian lainnya, penelitian ini meninjau penggunaan sistem informasi manajemen kurikulum yang digunakan PTKI. Penelitian kurikulum PTKI ditinjau dari aspek sistem informasi manajemen di Indonesia masih terbatas jumlahnya. Perguruan tinggi di Indonesia banyak yang belum memanfaatkan SIM kurikulum sebagai layanan kepada mahasiswa. Mempertimbangkan website menggunakan CMS Wordpress dipandang mudah dan menarik, penelitian ini difokuskan mengkaji implementasi SIM kurikulum PTKI berbasis CMS Wordpress di Prodi MPI FTK UIN Sunan Gunung Djati Bandung.

Perguruan Tinggi Keagamaan Islam sejatinya dapat mengikuti trend perkembangan teknologi informasi dan komunikasi. Karakteristik perkembangan teknologi pada era revolusi industri 4.0, meliputi digitalisasi, optimalisasi, kustomisasi produksi, otomasi dan adapsi, human machine interaction, value added services and businesses, automatic data exchange and communication, dan memadukan penggunaan teknologi internet (Iswan \& Herwina, 2018). Dalam menghadapi era disrupsi teknologi informasi dan komunikasi terdapat 51 perguruan tinggi negeri (PTN) yang siap menerapkan kuliah non tatap muka, sedangkan PTS masih terus berlomba meningkatkan proses kuliah komvensional menuju ke arah yang lebih baik. Di negara maju Pengembangan Cyber University sudah banyak diterapkan hal tersebut guna mencapai efktivitas dan efesiensi yang lebih baik.

Teknologi informasi pada saat ini telah mengalami perkembangan yang sangat pesat. Perkembangan teknologi informasi tersebut mampu meningkatkan kinerja dan memungkinkan berbagai kegiatan dapat dilakukan dengan cepat, tepat, dan akurat serta meningkatkan produktivitas kerja manusia. Salah satu dampak perkembangan teknologi informasi yaitu munculnya berbagai jenis kegiatan yang berbasis elektronik, seperti: e-government, $e$ commerce, e-education, dan kegiatan lainnya (Rikanita, 2017). Teknologi informasi sangat berpengaruh dalam dunia pendidikan. Hal tersebut dapat meningkatkan mutu pelayanan pendidikan kepada pelanggan.

Sistem informasi bisa disebut sebagai jaringan kerja dari prosedur-prosedur yang saling terkait dan terikat bersama-sama untuk melakukan suatu proses kerja atau untuk menyelesaikan suatu kegiatan tertentu atau merupakan kumpulan dari elemen-elemen yang berinteraksi untuk mencapai suatu tujuan yang telah ditentukan. Sistem informasi sebuah lembaga digunakan untuk mengetahui tingkat produktifitas dan kemajuan serta aktivitas yang terjadi pada Lembaga tersebut (Muliawan, Bondan, Satoto, Iman, \& Sumardi, 2011).

Kompleksitas organisasi memerlukan tersedianya suatu sistem informasi manajemen yang mampu membantu penyediaan data dan informasi untuk menjadi bahan penentuan kebijakan dan strategi pembangunan serta peneyediaan data dan informasi operasional. Data organisasi diproses dalam sebuah sistem 
untuk menjadi informasi yang membantu dalam pegambilan keputusan. Sistem informasi dalam pemahaman sederhana dapat didefinisikan sebagai suatu sistem berbasis komputer yang menyediakan informasi bagi beberapa pemakai dengan kebutuhan yang serupa.

Menurut Susanto \& Hendri (2015) ruang lingkup SIM terdapat pada tiga kata pembentuknya, yaitu: "sistem", "informasi", dan "manajemen". Sistem merupakan kumpulan prosedur yang memiliki hubungan satu sama lain yang membentuk satu kesatuan dalam usaha mencapai suatu tujuan. Informasi merupakan data yang telah diproses melalui sistem. Data yang diperoleh dari setiap elemen sistem tersebut menjadi bentuk yang mudah dipahami. Manajemen merupakan proses atau kegiatan yang dilakukan pengelola perusahaan seperti merencanakan, mengorganisasikan, memprakarsai, mengkoordinir, dan mengendalikan operasi untuk mencapai tujuan yang telah ditetapkan. Jadi, SIM sebagai sistem informasi yang menghasilkan keluaran (output) dengan menggunakan masukan (input) dan berbagai proses yang diperlukan untuk memenuhi tujuan tertentu dalam suatu kegiatan manajemen.

Teknologi memberikan dampak yang besar terhadap proses pembelajaran dan layanan pendidikan, termasuk layanan kurikulum bagi mahasiswa. Muatan yang terkandung dalam kurikulum harus diketahui oleh mahasiswa sehingga informai kurikulum harus diterapkan oleh lembaga pendidikan untuk meningkatkan kualitas layanan. Teknologi tidak selalu mahal, prodi MPI UIN SGD Bandung memanfaatkan CMS Wordpress, aplikasi SIM web versi gratis dalam memberikan layanan sistem informasi kurikulum kepada mahasiswanya. Penelitian ini bertujuan untuk mengeksplorasi dan mendeskripsikan: 1) Perencanaan penggunaan SIM kurikulum berbasis CMS Wordpress pada Prodi MPI FTK UIN SGD Bandung. 2) Pelaksanaan penggunaan SIM kurikulum berbasis CMSWordpress pada Prodi MPI FTK UIN
SGD Bandung. 3) Evaluasi penggunaan SIM kurikulum berbasis CMSWordpress pada Prodi MPI FTK UIN SGD Bandung.4) Konsep desain model SIM kurikulum berbasis CMSWordpress pada Prodi MPI FTK UIN SGD Bandung.

Sistem informasi manajemen adalah interaksi dari suatu sistem informasi yang menyajikan informasi baik untuk kepentingan operasi atau kegiatan. Sistem informasi manajemen mengolah data untuk gambaran ketersediaan suatu rangkaian informasi yang cukup lengkap yang disimpan dan disajiakan dalam bentuk informasi lain untuk mendukung implementasi, pengelolaan, dan pengambilan keputusan dalam suatu organisasi (Zakiyudin, 2011). Menurut Stoner, sistem informasi manajemen adalah suatu cara formal untuk menyajikan informasi yang akurat dan tepat waktu bagi manajemen yang diperlukan untuk membantu proses pengambilan keputusan, dan memungkinkan fungsi-fungsi dari manajemen dapat dilaksanakan secara efektif (Ismail \& Sinen, 2017). Berdasarkan beberapa pendapat tersebut, maka peneliti menyimpulkan bahwa sistem informasi manajemen adalah suatu sistem yang desain untuk mengolah data menjadi informasi guna mendukung pengambilan keputusan pada kegiatan manajemen dalam suatu organisasi.

Pemerintah melalui Peraturan Presiden Republik Indonesia Nomor 08 Tahun 2012 tentang Kerangka Kualifikasi Nasional Indonesia (KKNI) mengharuskan kurikulum PT disusun sesuai dengan kerangka yang termaktub dalam KKNI tersebut. KKNI merupakan kerangka penjenjangan kualifikasi kompetensi yang yang diterapkan untuk menyandingkan, menyetarakan, dan mengintegrasikan antara bidang pendidikan dan bidang pelatihan kerja serta pengalaman kerja dalam rangka memberikan pengakuan kompetensi kerja sesuai dengan struktur pekerjaan di berbagai sektor (Tim Kerja, 2014). Permenristekdikti Nomor 44 Tahun 2015 tentang Standar Nasional Pendidikan Tinggi) memuat standar nasional pendidikan, 
standar penelitian dan standar pengabdian kepada masyarakat. Kurikulum termasuk dikaji pada standar nasional pendidikan.

\section{METODE PENELITIAN}

Penelitian ini menggunakan pendekatan kualitatif, karena memenuhi ciriciri penelitian kualitatif, yaitu kondisi objek penelitian alamiah. Peneliti sebagai instrumen utama, bersifat deskriptif, lebih mementingkan proses dari pada hasil, dan data yang terkumpul diolah secara mendalam. Data yang dikumpulkan bukan berupa angka angka, melainkan data tersebut berasal dari hasil wawancara, catatan lapangan, dokumen pribadi, catatan memo, dan dokumen resmi lainnya. Sehingga yang menjadi tujuan dari penelitian kualitatif ini adalah menggambarkan realita empirik di balik fenomena secara mendalam, rinci dan tuntas.

Peneliti menggambarkan atau memaparkan data yang diperoleh berkaitan dengan manajemen sistem informasi kurikulum PTKI mengunakan CMS Wordpress melalui metode studi kasus di Prodi MPI (Manajemen Pendidikan Islam) Fakultas Tarbiyah dan Keguruan UIN Sunan Gunung Djati Bandung. Sumber data penelitian ini adalah Ketua Prodi MPI (Manajemen Pendidikan Islam) Fakultas Tarbiyah dan Keguruan UIN SGD Bandung, Operator Sistem Informasi Manajemen Kurikulum Prodi MPI, dan aplikasi CMS Wordpress yang digunakan pada lembaga tersebut. Pengumpulan data menggunakan teknik observasi, studi dokumentasi, dan wawancara. Data yang diperoleh peneliti diolah dalam hasil penelitian kemudian dibahas dan akhirnya menjadi simpulan.

Analisis data penelitian dilakukan dengan cara mengumpulkan data, mereduksi, dan memeriksa keabsahan data, menyajikan, serta menafsirkan data. Peneliti menyusun data ke dalam tema dan kategori agar dapat ditafsirkan dan diinterpretasikan. Peneliti berusaha untuk menyusun dan mengolah data agar benar-benar bermakna.

\section{HASIL DAN PEMBAHASAN}

\section{Perencanaan penggunaan SIM kurikulum berbasis CMS Wordpress}

Perencanaan adalah proses mengantisipasi dan membuat ketentuan (persyaratan) untuk mengatur arus gerakan sumber di dalam organisasi. Perencanaan merupakan serangkaian kegiatan yang berkaitan dengan upaya merencanakan dalam mengantisipasi masa depan (Sunarta, 2017). Pengertian tersebut menunjukkan bahwa perencanaan merupakan aktivitas organisasi menentukan sejumlah tindakan yang akan dilakukan pada masa yang akan datang.

Prodi MPI Fakultas Tarbiyah dan Keguruan UIN SGD Bandung merencanakan SIM kurikulum berbasis CMS Wordpress sebagai bentuk peningkatan layanan informasi kepada mahasiswa dan merespon perkembangan informasi digital revolusi industri 4.0.yang menjadikan penggunaan data digital dan IoT (Internet of Things) menjadi alasan penggunaan SIM tersebut (Wawancara dengan operator Prodi MPI FTK UIN SGD Bandung Hidayat, Bandung 12 Februari 2019)

Wordpress adalah salah satu media paling populer untuk membuat website baik berupa blog pribadi, situs perusahaan (company profil), situs pendidikan, bahkan situs komersil seperti toko online. Wordpress hadir pertama kali tahun 2003 sebagai pengembangan dari aplikasi log b-2/cafelog oleh Matt Mullenweg dan Mike Little. Awalnua wordpress berfokus pada media log pribadi tempat konten Web diurutkan berdasarkan kronologis berkembang menjadi aplikasi CMS yang bisa digunakan untuk membuat website diluar blog, seperti online shop, corporate website, dan situs edukasi. Saat ini wordpress termasuk ke dalam aplikasi CMS (Content Management System). CMS adalah suatu sistem untuk men-publish, mengedit, memodifikasi, menghapus dan mengorganisasi kontent secara terpusat (wikipedia). Kontent yang dimaksud adalah artikel yang akan menjadi isi dari website. 
CMS merupakan perangkat lunak yang digunakan untuk mengelola konten digital. Yang dimaksud dengan digital adalah semua bentuk informasi digital, yang berupa file citra, audio, video, teks, dan data komputer lainnya. CMS berbentuk aplikasi berbasis web yang diterapkan menggunakan bahasa pemrograman yang memiliki kemampuan pemrograman berbasis web. CMS mempermudah pengelolaan konten digital sehingga pengelolaan website bisa dilakukan oleh orang awam yang tidak mahir dalam bidang teknologi informasi. Penggunaanya mirip dengan penggunaan media sosial.

CMS Wordpress adalah sebuah aplikasi computer sumber terbuka (open source) yang sangat populer digunakan sebagai mesin blog (blog engine). Aplikasi tersebut dikembangkan dengan bahasa pemrograman PHP dan basis data (database) MySQL. PHP dan MySQL, keduanya Bahasa pemograman tersebut merupakan perangkat lunak sumber terbuka (open source software). Selain sebagai blog, CMS Wordpress juga mulai digunakan sebagai sebuah CMS (Content Management System) karena kemampuannya untuk dimodifikasi dan disesuaikan dengan kebutuhan penggunanya. CMS Wordpress adalah penerus resmi dari b2/cafelog yang dikembangkan oleh Michel Valdrighi. Nama CMS Wordpress diusulkan oleh Christine Selleck, teman Matt Mullenweg. CMS Wordpress saat ini menjadi platform content management system (CMS) bagi beberapa situs berita seperti CNN, Reuters, The New York Times, TechCrunch, dan lainnya (Siambaton \& Fakhriza, 2016, p. 11).

CMS wordpress memberikan layanan editor tema, sehingga pengguna CMS tersebut tidak perlumempelajari bahasa pemograman yang rumit untuk membangun website. Wordpress memiliki 4063 tema yang bisa diterapkan pada web penggunanya. Dari tema tersebut tersedia versi gratis dan berbayar. Versi gratis hanya memiliki tema standar pengelolaan data digital. Sedangkan versi berbayar memberikan fasilitas lebih dengan adanya aplikasi-aplikasi tambahan yang lebih memudahkan dalam pengelolaan web. Ketersediaan plug in atau aplikasi tambahan yang lengkap menjadi daya tarik wordpress bagi kalangan profesional.

Perencanaan penggunaan CMS Wordpress sebagai aplikasi pengelola web didasarkan pada analisis SWOT (Strength, Weakness, Opportunity, Treat) yang dilakukan Prodi MPI dengan hasil analisis sebagai berikut: 1) Potensi (strong): a) bahwa Prodi MPI telah memiliki web yang merupakan subdomain dari web universitas dengan alamat mpi.uinsgd.ac.id; b) subdomain tersebut sudah ter-install aplikasi CMS Wordpress untuk menghemat biaya; c) Prodi memiliki SDM yang kompeten dalam pengembangan wordpress tempat pengelolaan web tersebut yang ditangani langsung oleh sekretaris prodi sebagai admin utama. 2) Prodi tersebut juga mengidentifikasi kelemahan (weakness) yang berkaitan dengan pengembangan SIM kurikulum tersebut yaitu bahwa sebagian dosen masih kesulitan dalam menggunakan SIM tersebut. 3) Prodi MPI merumuskan peluang (opportunities) yang mungkin bisa didapatkan yaitu bahwa: a) penggunaan SIM kurikulum tersebut dapat meningkatkan layanan terhadap mahasiswa yang berdampak pada kepuasan mahasiswa; b) Prodi MPI berpeluang melakukan penyebaran informasi Prodi MPI melalui informasi digital di dunia maya. 4) Tantangan (treat) yang diidentifikasi oleh prodi MPI, yaitu: a) Prodi memiliki tantangan untuk meningkatkan partisifasi dosen dalam penggunaan SIM kurikulum; b) Dosen masih sulit berperan aktif dalam pengumpulan data kurikulum dan penayangan dokumen kurikulum.

Prodi MPI UIN SGD juga mengidentifikasi alasan dalam memilih CMS Worpress sebagai alat yang digunakan untuk sitem informasi manajemen kurikulum. Hasil identifikasi prodi alasan pemilihan CMS Wordpress sebagai berikut: 1) CMS wordpress memiliki versi tidak berbayar, sehingga memberikan efesiensi biaya. 2) Wordpress memiliki tampilan editor 
blogging sehingga tidak memerlukan editor yang memiliki kemampuan bahasa pemrograman. 3) CMS wordpress memiliki kompatibilitas terhadap smartphone.

Perencanaan penggunaan

CMS

Wordpress Prodi MPI memuat profil Prodi MPI, akademik, dosen, pengembangan jurusan, himpunan mahasiswa jurusan, Gallery, dan perpustakaan Prodi MPI. Perencanaan penggunaan kurikulum berbasis CMS Wordpress pada Prodi MPI memuat struktur kurikulum, sebaran mata kuliah dalam semester, bobot sks, dan RPS.

Perencanaan penggunaan kurikulum berbasis CMS Wordpress pada Prodi MPI dapat meningkatkan mutu layanan akademik kepada dosen, mahasiswa, dan tenaga kependidikan serta mendukung pencapaian tujuan Prodi MPI secara efektif dan efisien. Hasil analisis menunjukkan bahwa perencanaan Sistem Informasi Manajemen Kurikulum Prodi MPI UIN SGD Bandung sudah mengunakan pendekatan SWOT, Potesni yang dianalisis mencakup ketersediaan server dan admin web. Perguruan tinggi memiliki komponen yang lebih besar seperti dosen dan mahasiswa. Potensi mahasiwa di era milenial memiliki ketertarikan penggunaan IT yang lebih besar dari generasi sebelumnya. Potensi ini layak dianalisis lebih dalam seperti analisis penggunaan jenis sistem informasi dan jenis smartphone yang digunakan dosen dan mahasiswa. Hal tersebut diharapkan dapat menjadi bahan masukan pada perencanaan dan target yang akan dicapai.

\section{Pelaksanaan Penggunaan SIM Kurikulum Berbasis CMS Wordpress}

Kata kurikulum (curriculum) berasal dari bahasa Yunani, yaitu curir yang memiliki arti "pelari" dan curere yang berarti "tempat berpacu". Istilah kurikulum diambil dari dunia olahraga, terutama dalam bidang atletik pada zaman Romawi Kuno di Yunani. Kurikulum dapat diartikan suatu lintasan yang harus ditempuh oleh seorang pelari mulai dari garis start sampai dengan garis finish untuk memperoleh kemenangan.
Lintasan tersebut kemudian diadaftasi menjadi kegiatan Pendidikan di sekolah dan semua orang yang terlibat didalamnya. Kurikulum itu sendiri merupakan perangkat mata ajar dan program pendidikan yang diterapkan kepada peserta didik oleh suatu lembaga pendidikan dalam satu periode jenjang Pendidikan (Gunawan \& Triantoro, 2017).

Sistem informasi manajemen kurikulum yang dimaksud merupakan implementasi aplikasi sebagai pendukung kegiatan fungsi manajemen guna menunjang tercapainya sasaran dan fungsi-fungsi operasional lembaga pendidikan dalam mengelola kurikulum. Dengan adanya sistem informasi manajemen kurikulum, organisasi pendidikan mendapatkan beberapa manfaat sebagai berikut: Pertama, tersedianya sistem pengelolaan data dan informasi kurikulum. Kedua, terintegrasinya data dan informasi pendidikan untuk mendukung proses pengambilan keputusan kegiatan pembelajaran. Ketiga tersedianya gambaran informasi pendidikan yang lengkap bagi seluruh stakholders yang bergabung dalam bidang pendidikan. Sistem informasi manajemen kurikulum digunakan oleh penggunanya sebagai alat bantu pengambil keputusan dan oleh pihak yang tergabung didalamnya sehingga anggota organisasi pendidikan dapat melakukan interaksi dengan pihak berkepentingan (stakeholders). Nilai penting sistem informasi manajemen kurikulum sebagai bagian SIM pendidikan adalah: 1) Sistem informasi yang berbasis komputer memungkinkan otomasi kegiatan rutin. 2) Teknologi informasi memungkinkan pengolahan data secara lebih akurat dan andal. 3) Pengambilan keputusan ditunjang dengan pilihan alternatif yang lebih objektif dengan data pendukung yang lengkap. 4) kegiatan manajemen membutuhkan informasi secara cepat dan efisien (Ismail \& Sinen, 2017) SIM Kurikulum adalah sistem manajemen basis data SIM tersebut merupakan sebuah tatanan (keterpaduan) yang terdiri atas sejumlah elemen fungsional (komputer) yang terhubung dan terikat 
secara bersama-sama melakukan suatu proses atau pekerjaan tertentu. Sistem ini merupakan gabungan antara basis data dan kumpulan program atau perangkat lunak yang disebut DBMS (Database Management System) (Asmoro \& Herlawati, 2016).

Pihak yang terlibat dalam penggunaan SIM kurikulum berbasis CMS Wordpress adalah dosen, mahasiswa, dan tenaga kependidikan (operator/admin). Penggunaan kurikulum berbasis CMS Wordpress pada Prodi MPI melibatkan semua dosen dalam mengunggah RPS (Rencana Pembelajaran Semester), menyajikan bahan ajar, menentukan sumber belajar, dan menentukan penilaian hasil belajar. RPS yang tersimpan pada Web digunakan agar menjadi acuan perkuliahan mahasiswa dan dosen. Setiap dosen membat RPS dengan komponen yang telah ditentukan prodi. RPS tersebut diserahkan kepada operator SIM dalam bentuk softfile dengan format PDF. Setelah RPS diterima, operator mengunggah file RPS tersebut sehingga tampil pada halaman web. Proses unggah data RPS pada CMS Wordpress sebagai berikut: 1) Admin melaksanakan login terlebih dahulu ke laman web prodi MPI. 2) Setelah login, admin mengunggah file PDF RPS yang diterima dari dosen. 3) Admin membuat tulisan baru dengan menyisifkan file RPS yang telah diunggah dengan metode $p d f$. embedder sehingga file RPS tampil pada halaman tulisan baru sesuai dengan judul.

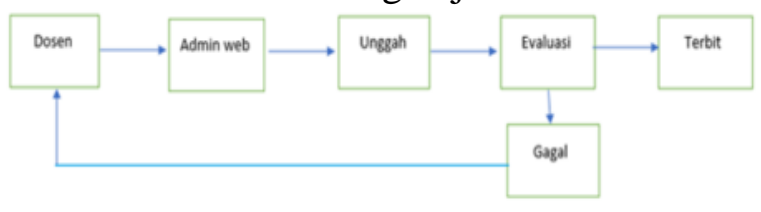

Gambar.1 Alur penerbitan RPS

(Sumber Dokumen Kurikulum Prodi MPI, 2019)

Setelah RPS terbit maka informasi tersebut bisa digunakan oleh mahasiswa dan dosen sebagai acuan perkuliahan, menyangkut capaian pembelajaran lulusan, materi perkuliahan, sumber belajar yang digunakan dan penilaian pembelajaran.
Implementasi proses penerbitan RPS dikelola oleh operator hal tersebut memberikan banyak beban ditujukan pada operator karena operator di lembaga tersebut adalah sekertaris Prodi. Idealnya admin wordpress bisa membuat banyak akun. Akun tersebut bisa diberikan kepada msaingmasing dosen dan mahasiswa sehingga seluruh dosen dan mahasiswa bisa ikut langsung berkontribusi menuliskan konten pada sistem informasi Prodi seperti RPS, Tugas Mahasiswa dan informasi lain yang berhubungan dengan Prodi. Hal tersebut bisa diterapkan apabila kemampuan IT dosen dan mahasiswa sudah mempuni.

Wordpress dipilih sebagai aplikasi pengelola kurikulum karena kelebihan yang ditawarkan oleh pengembang aplikasi tersebut seperti tema dan aplikasi tambahan yang menunjang pengelolaan dokumen kurikulum. Aplikasi tambahan yang digunakan pada web tersebut diantaranya, doc emmbeder, merupakan aplikasi tambahan wordpress yang berguna bagi pengelola dokumen berjenis PDF dan docx. Dengan aplikasi tersebut sebuah web dengan mudah menampilkan dokumen tanpa harus mengunduh file tersebut. Web Prodi tersebut juga menggunakan aplikasi tambahan yang bernama elementor. Aplikasi tersebut membantu admin untuk menambahkan tombol dan menu-menu web secara praktis tanpa harus membuat kode bahasa pemograman. Aplikasi yang lain adalah instagram gallery, aplikasi tersebut berguna untuk menghubungkan sosial media instagram kedalam website. Website Prodi MPI UIN Bandung hanya mengunakan tiga aplikasi tambahan, idealnya sebuah web menggunakan 8-15 aplikasi tambahan yag bisa membantu pengelolaan sitem informasi akan tetapi dari semua aplikasi tambahan yang tersedia di wordpress tidak gratis, pemilik harus membeli aplikasi tersebut karena beberapa aplikasi gratis bersifat sementara dalam penggunaannya.

Web MPI UIN SGD Bandung mengunakan tema magazine wespaper tema tersebut memiliki dua versi, yaitu versi 
berbayar dan versi gratis. Versi yang digunakan pada web Prodi MPI FTK UIN SGD Bandung adalah versi gratis. Versi gratis memiliki keterbatasan dalam pengelolaan tampilan. Tampilan web terkesan kaku dan kostumisasi web menjadi sulit disesuaikan. Adapun CMS sejenis yang bisa di gunakan sebagai sistem informasi adalah CMS Joomla, CMS tersebut memiliki lisensi yang gratis sama halnya wordpress. Akan tetapi CMS tersebut sulit digunakan oleh pengguna yang awam. Jumlah tema dan plug in yang tersedia tidak sebanayak di wordpress. Apabila prodi Memiliki SDM IT yang memadai joomla layak dijadikan CMS pengganti wordpress karena compatibilitas yang tinggi sehingga joomla mudah disesuaikan oleh pengguna web.

\section{Evaluasi Penggunaan SIM Kurikulum Berbasis CMS Wordpress}

Evaluasi Penggunaan SIM Kurikulum Berbasis CMS Wordpress pada Prodi MPI FTK UIN SGD Bandung dilakukan untuk menggambarkan bahwa ada keterkaitan antara perencanaan kurikulum, pelaksanaan kurikulum, dan pengawasan kurikulum. Pengawasan kurikulum membantu dalam memastikan perencanaan, pengorganisasian, dan pengawasan kurikulum terlaksana dengan baik. Fungsi pengawasan memiliki empat unsur yaitu (1) penetapan standar pelaksanaan, (2) penentuan ukuran-ukuran pelaksanaan, (3) pengukuran pelaksanaan nyata yaitu membandingkan dengan standar yang telah ditetapkan, dan (4) pengambilan tindakan koreksi yang diperlukan bila pelaksanaan menyimpang dari standar.

Evaluasi Penggunaan SIM Kurikulum Berbasis CMS Wordpress pada Prodi MPI FTK UIN SGD Bandung merupakan evaluasi program penggunaan SIM kurikulum berbasis CMS Wordpress. Ada dua jenis evaluasi pada penggunaan SIM Kurikulum di prodi MPI, evaluasi tersebut adalah evaluasi konten RPS dan evaluasi sistem web. Prodi menetapkan beberapa standar atas konten RPS (Rencana Pembelajaran Semester) yang harus di terbitkan. Standar yang digunakan tersebut adalah standar SMART (spesific, measurable, achievable, realistic, time bond). RPS yang diterbitkan harus jelas, menggunakan istilah yang spesifik menggambarkan kemampuan pengetahuan, nilai, sikap dan kinerja yang diinginkan, menggunakan kata-kata tindakan atau kata kerja nyata. RPS harus mempunyai target dan hasil yang dapat diukur atau diamati, sehingga dapat menentukan waktu pencapaiannya oleh mahasiswa. RPS harus memuat target kemampuan yang diinginkan dan target tersebut adalah sesuatu yang mahasiswa dapat mencapainya dalam aktivitas belajar. RPS harus menunjukan kemampuan mahasiswa yang diinginkan, realistis, dan relevan untuk dicapai mahasiswa. RPS memiliki alokasi waktu yang diperlukan oleh mahasiswa untuk mencapai kemampuan yg diinginkan secara wajar dan terarah. Prodi menetapkan standar untuk web sistem informasi kurikulum tempat standar tersebut pada web. Web harus mudah diakses oleh pengguna, kompatibel untuk semua alat komunikasi yang digunakan dosen dan mahasiswa, dan keamanan dokumen terjaga dari plagiat.

Evaluasi konten RPS dan SIM kurikulum berbasis CMS Wordpress dilakukan oleh Ketua Prodi MPI. Hasil evaluasi konten RPS diberitahukan kepada dosen yang bersangkutan sehingga ada perbaikan. Sedangkan untuk evaluasi SIM Kurikulum di beritahukan kepada admin/sekertaris jurusan untuk dilakukan perbaikan.

Evalusi RPS dilakukan oleh ketua Prodi setelah dokumen RPS selesai dibuat. Menurut teori evaluasi dapat dilakukan tiga tahap, yaitu di awal, ditengah dan di akhir. Evaluasi awal dapat dilakukan pada dokumen RPS selesai dibuat oleh dosen, evalusi tengah dapat dilakukan ketika proses penggunaan RPS dilakukan, misalnya pada saat perkuliahan prodi melakukan evaluasi RPS dan memberikan catatan hasil evaluasi pada halaman konten RPS di website program studi. Evaluasi akhir dapat 
dilakukan setelah akhir semester menggunakan standar yang ditetapkan prodi dan melibatkan pendapat mahaiswa, hasil evaluasi tersebut bisa ditambahkan pada halaman RPS di web prodi sehingaa hasil evaluasi bisa didokumentasikan dan di simpan.

\section{Konsep desain model SIM kurikulum berbasis CMS wordpress}

Prodi menerapkan konsep dasar pada desain SIM kurikulum dengan menentukan aplikasi yang digunakan, format gambar yang sesuai, pemilihan warna teks, dan latar belakang sebuah halaman web. Berikut ini terdapat beberapa aspek yang diperhatikan pada desain SIM kurikulum Prodi, yaitu: 1) Dapat Dijalankan dan digunakan (usebility). 2) web mampu menampilkan dokumen kurikulum secara cepat walaupun diakses pada smartphone. 3) Web memiliki dua navigasi (navigation), navigasi utama dan navigasi tambahan. Navigasi utama yaitu menu Home, profil, akademik, dosen, pengembangan jurusan dan galerry dan perpustakaan. Navigasi tambahan terdiri dari empat tombol menu yaitu RPS MPI, SIM Kurikulum, jaringan alumni dan E-book MPI.

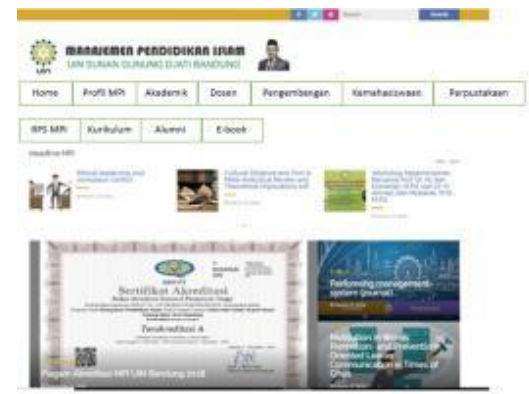

Gambar.2 Tampilan Beranda web MPI Uin SGD versi dekstop (Sumber Dokumen Kurikulum Prodi MPI FTK UIN SGD Bandung)

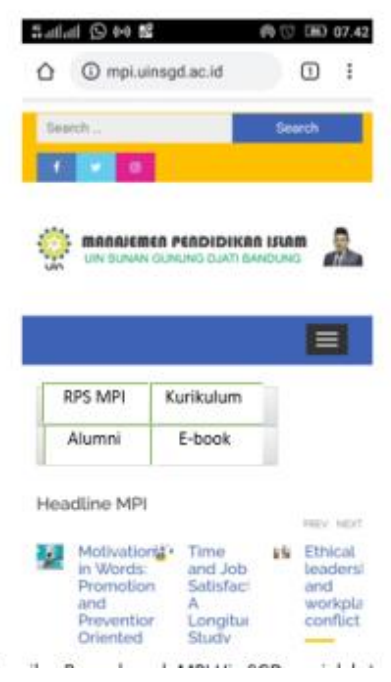

Gambar.3 Tampilan Beranda web MPI FTK UIN SGD versi mobile (Sumber Dokumen Kurikulum Prodi MPI FTK UIN SGD Bandung, 2019)

SIM Kurikulum Prodi MPI UIN SGD Bandung juga memiliki menu serach, menu tersebut untuk mempermudah melakukan pencarian pada konten web. Apabila penguna ingin mencari RPS yang dimaksud cukup mengetik nama RPS tersebut.

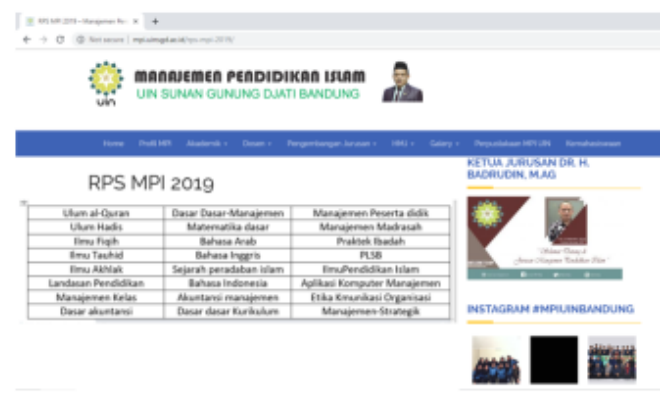

Gambar.4 Tampilan menu pilihan RPS versi dekstop (Sumber Dokumen Kurikulum Prodi MPI FTK UIN SGD Bandung)

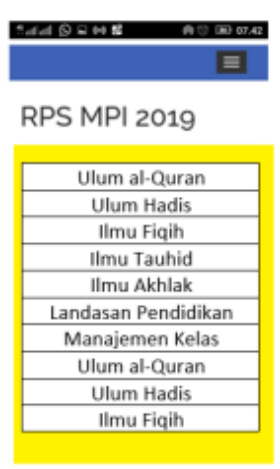

Gambar.5 Tampilan menu pilihan RPS versi mobile 
(Sumber Dokumen Kurikulum Prodi MPI FTK UIN SGD Bandung)

Menu RPS dimuat pada Web untuk mempermudah navigasi, pengguna cukup memilih tombol RPS yang dimaksud. Setelah itu akan lanjut ke halaman berikutnya yang memuat RPS secar langsung tanpa diunduh.

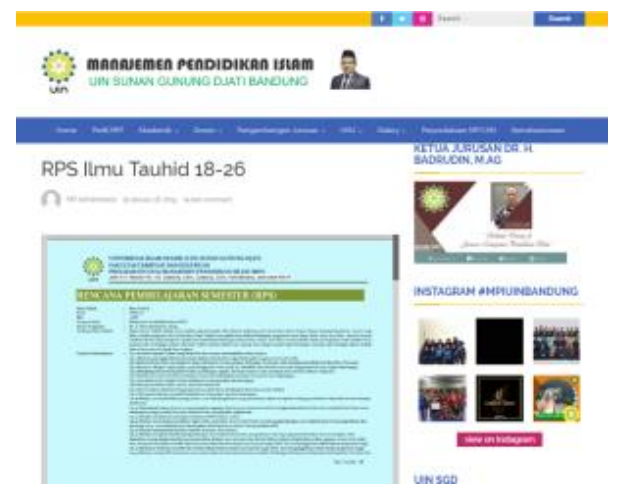

Gambar.6 Tampilan RPS PDF versi dekstop (Sumber Dokumen Kurikulum Prodi MPI FTK UIN SGD Bandung)

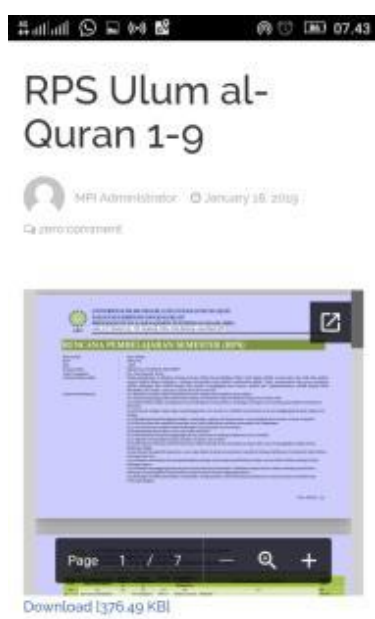

Gambar.7 Tampilan RPS PDF versi mobile (Sumber Dokumen Kurikulum Prodi MPI FTK UIN SGD Bandung, 2019)

RPS diterbitkan secara langsung pada browser setelah pengguna memilih navigasi RPS yang dimaksud. RPS yang merupakan file berjenis PDF ditampilkan langsung tanpa diunduh sehingga mempercepat proses penampilan file. Apabila pengguna ingin mengunduh dan menyimpan file tersebut, pengguna dapat memilih navigasi yang ada dibawah tampilan RPS sehingga RPS akan terunduh dan disimpan secara otomatis

\section{KESIMPULAN DAN REKOMENDASI}

Selain beberapa kelebihan, penggunaan CMS Wordress memiliki sejumlah kekurangan untuk menjadi aplikasi kurikulum PTKI di antaranya (a) Desain web terbatas pada tema yang disediakan oleh pengembang Wordpress, (b) Admin web yang memiliki kemampuan kode web tidak bisa bebas mengembangkan aplikasi CMS tersebut, berbeda dengan CMS Joomla yang memiliki Compatibilities yang tinggi yaitu Prodi bisa leluasa membuat desain dan tampilan yang lebih baik. (c) Tema gratis umumnya sederhana, sedangkan tema yang memiliki kualitas yang baik memiliki harga yang cukup mahal.

Sistem Informasi Manajemen kurikulum berbasis CMS Wordpress pada Program Studi Manajemen Pendidikan Islam Fakultas Tarbiyah dan Keguruan UIN SGD Bandung dilakukan melalui sejumlah tahap yaitu perencanaan, pelaksanaan, dan evaluasi penggunaan serta penyusunan konsep desain model kurikulum berbasis CMS Wordpress. Pihak yang terlibat dalam penggunaan SIM kurikulum berbasis CMS Wordpress Prodi MPI FTK UIN SGD Bandung yaitu dosen, mahasiswa, dan tenaga kependidikan (operator). Pada tahap perencanaan, dosen membuat RPS yang digunakan acuan perkuliahan. Setiap dosen membuat RPS selanjutnya RPS tersebut diserahkan kepada operator SIM dalam bentuk softfile dengan format PDF. Setelah RPS diterima operator, maka operator mengunggah file RPS tersebut sehingga tampil pada halaman web. Prodi menetapkan beberapa standar atas konten RPS yang harus di terbitkan, standar yang digunakan tersebut adalah standar SMART. Konsep dasar desain SIM kurikulum diterapkan Prodi MPI mulai tool 'alat' yang digunakan, format gambar yang sesuai, hingga pemilihan warna teks dan latar belakang halaman web. Web memiliki dua navigasi (navigation). Navigasi utama dan navigasi tambahan. Navigasi utama yaitu 
menu Home, profil, akademik, dosen, pengembangan jurusan dan galerry,serta perpustakaan. Navigasi tambahan terdiri dari empat tombol menu yaitu RPS MPI, SIM kurikulum, profil sjaringan alumni, dan Ebook MPI. Direkomendasikan peneliti selanjutnya dapat mengembangkan efektivitas model SIM kurikulum berbasis CMS Wordpress pada Perguruan Tinggi Keagamaan Islam.

\section{REFERENSI}

Alhamuddin. (2016). Kurikulum Pendidikan Tinggi Keagamaan Islam: Mutu dan relevansi. Jurnal Al Murrabi, 3(1), 115. Retrieved from http://ejournal.kopertais4.or.id/matara man/index.php/murabbi/article/view/ 1698

Asmoro, P., B., \& Herlawati. (2016). Sistem Informasi Ujian Berbasis Web Pada SD Islam Teratai Putih Global Bekasi. Journal of Informatics, 1(1), 109-123. Retrieved from http://ejournalbinainsani.ac.id/index.php/ITBI/articl e/view/180

Dokumen Kurikulum Prodi MPI. (2019). Fakultas Tarbiyah dan Keguruan UIN Sunan Gunung Djati Bandung.

Gunawan, H., \& Triantoro, A. (2017). Sistem Informasi Pengolahan Rapor Kurikulum 2013 (Studi Kasus: SMKN 2 Purwokerto). Jurnal Terapan Teknologi Informasi, 1(1). https://doi.org/DOI 10.21460/jutei.2017.11.6

Hidayat, D. (2019, February 12). Operator Prodi MPI FTK UIN SGD Bandung.

Ismail, L. O., \& Sinen, R. (2017). Penerapan Sistem Informasi Manajemen Pendidikan dalam Proses Pembelajaran Di Smp Negeri 21 Makassar. Idaarah: Jurnal Manajemen Pendidikan, 1(2). https://doi.org/10.24252/idaarah.vli2. 4272

Iswan, \& Herwina, B. (2018). Penguatan Pendidikan Karakter Perspektif Islam dalam Era Millenial IR. 4.0. 1, 2142. Retrieved from https://jurnal.umj. ac.id/index.php/SNP/article/view/275 6

Muliawan, Bondan, Satoto, Iman, K., \& Sumardi. (2011). Rancang Bangun Sistem Informasi Akademik Berbasis Web Studi Kasus di Teknik Elektro Universitas Diponegoro, STIMIK AKI, dan IAIN Walisongo (Thesis, Universitas Dipenogoro). Retrieved from http://eprints.undip.ac.id/25934/

P. Anjarkusuma, D., \& Bambang, S. (2014). Penggunaan Aplikasi CMS Wordpress untuk Merancang Website Sebagai Media Promosi pada Maroon Wedding Malang. Jurnal Akuntansi, Ekonomi, Dan Manajemen Bisnis, 2(1), 63-69. Retrieved from https://jurnal.polibatam.ac.id/index.p $\mathrm{hp} / \mathrm{JAEMB/article/view/135}$

Permenristekdikti Nomor 44 Tahun 2015 tentang Standar Nasional Pendidikan Tinggi.s Biro Hukum dan Organisasi. Kementerian Riset, Teknologi, dan Pendidikan tinggi.

Peraturan Presiden Republik Indonesia Nomor 08 Tahun 2012 tentang Kerangka Kualifikasi Nasional Indonesia. Jakarta: Kementerian Hukum dan HAM RI.

Rikanita. (2017). Pengembangan Sistem Informasi Sekolah Berbasis Website Di SMK Negeri 1 Makassar (Pascasarjana, Universitas Negeri Makassar). Retrieved from shorturl.at/begiH

Siambaton, M., Z., \& Fakhriza, M. (2016). Aplikasi Content Management System (CMS) Pada Joomla Untuk Membuat Web Service. Infotekjar: Jurnal Nasional Informatika Dan 
Teknologi Jaringan), 1(1), 11. https://doi.org/10.30743/infotekjar.v1 i1.32

Sunarta. (2017). Perencanaan Sumber Daya Manusia (Kunci Keberhasilan Organisasi). Jurnal Informasi: Kajian Ilmu Komunikasi, XXXVI (2), 5. https://doi.org/10.21831/informasi.v2 i 2.6197

Susanto, \& Hendri, M. (2015). Pengembangan Sistem Informasi manajemen Pendidik dan Tenaga Kependidikan. Jurnal Pendidikan Humaniora, 3(2), 93-105. Retrieved from journal.um. ac.id/index.php/jph /article/view/4852/2300

Suwadi. (2016). Pengembangan Kurikulum PAI pada Pendidikan Tinggi
Mengacu KKNI-SNPT berparadigma Integrasi-Interkoneksi di Program Studi PAI FITK UIN Sunan Kalijaga. Jurnal Pendidikan Agama Islam, 13(2), 223-252. http:// dx.doi.org/10.14421/jpai.2016.13208

Tim Kerja. (2014). Kurikulum Pendidikan Tinggi. Jakarta: Direktorat Pembelajaran dan Kemahasiswaan. Direktorat Jenderal Pendidikan Tinggi. Kementerian Pendidikan dan Kebudayaan.

Zakiyudin, A. (2011). Sistem Informasi Manajemen. Jakarta: Mitra Wacana Media.

\section{Article Metadata:}

Badrudin. (2019). Management Information System (MISS) of the Curriculum of Islamic higher Education Institutions Based on CMS WordPress. Ta'dib, 22 (1), 1-12.

http://dx.doi.org/10.31958/jt.v22i1.1416

Keywords: Management Information System (MIS), Curriculum, CMS Wordpress.

Coresponding author: Badrudin, Universitas Islam Negeri Sunan Gunung Djati Bandung, dr.badrudin@uinsgd.ac.id 